Article

\title{
Catalytic Performance of Metal Oxides Promoted Nickel Catalysts Supported on Mesoporous $\gamma$-Alumina in Dry Reforming of Methane
}

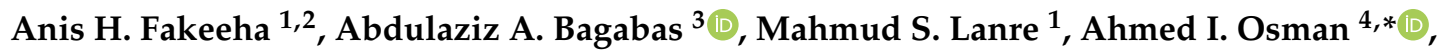 \\ Samsudeen O. Kasim $\left.{ }^{1}{ }^{(}\right)$, Ahmed A. Ibrahim ${ }^{1}{ }^{(\mathbb{C}}$, Rasheed Arasheed ${ }^{3}$, Abdulmajeed Alkhalifa $^{3}$, \\ Ahmed Y. Elnour ${ }^{1}\left(\mathbb{D}\right.$, Ahmed E. Abasaeed ${ }^{1}$ (D) and Ahmed S. Al-Fatesh ${ }^{1, *}$ \\ 1 Chemical Engineering Department, College of Engineering, King Saud University, P.O. Box 800, Riyadh \\ 11421, Saudi Arabia; anishf@ksu.edu.sa (A.H.F.); mahmudsofiu@gmail.com (M.S.L.); \\ sofkolajide2@gmail.com (S.O.K.); aididwthts2011@gmail.com (A.A.I.); aelnour@ksu.edu.sa (A.Y.E.); \\ abasaeed@ksu.edu.sa (A.E.A.) \\ 2 King Abdullah City for Atomic and Renewable Energy, (K.A. CARE) Energy Research and Innovation \\ Center at Riyadh, Riyadh 11421, Saudi Arabia \\ 3 National Petrochemical Technology Center (NPTC), Materials Science Research Institute (MSRI), King \\ Abdulaziz City for Science and Technology, P.O. Box 6086, Riyadh 11442, Saudi Arabia; \\ abagabas@hotmail.com (A.A.B.); rrisheed@kacst.edu.sa (R.A.); aalkhalifah@kacst.edu.sa (A.A.) \\ 4 School of Chemistry and Chemical Engineering, Queen's University Belfast, Belfast BT9 5AG, Northern \\ Ireland, UK \\ * Correspondence: a.osman@qub.ac.uk (A.I.O.); aalfatesh@ksu.edu.sa (A.S.A.-F.); \\ Tel.: +44-28-9097-4412 (A.I.O.); +966-11-4676859 (A.S.A.-F.)
}

Received: 14 April 2020; Accepted: 26 April 2020; Published: 28 April 2020

\begin{abstract}
Dry reforming of $\mathrm{CH}_{4}$ was conducted over promoted Ni catalysts, supported on mesoporous gamma-alumina. The Ni catalysts were promoted by various metal oxides $\left(\mathrm{CuO}, \mathrm{ZnO}, \mathrm{Ga}_{2} \mathrm{O}_{3}\right.$, or $\mathrm{Gd}_{2} \mathrm{O}_{3}$ ) and were synthesized by the incipient wetness impregnation method. The influence of the promoters on the catalyst stability, coke deposition, and $\mathrm{H}_{2} / \mathrm{CO}$ mole ratio was investigated. Stability tests were carried out for $460 \mathrm{~min}$. The $\mathrm{H}_{2}$ yield was $87 \%$ over $5 \mathrm{Ni}+1 \mathrm{Gd} / \mathrm{Al}$, while the $\mathrm{CH}_{4}$ and $\mathrm{CO}_{2}$ conversions were found to decrease in the following order: $5 \mathrm{Ni}+1 \mathrm{Gd} / \mathrm{Al}>5 \mathrm{Ni}+1 \mathrm{Ga} / \mathrm{Al}>$ $5 \mathrm{Ni}+1 \mathrm{Zn} / \mathrm{Al}>5 \mathrm{Ni} / \mathrm{Al}>5 \mathrm{Ni}+1 \mathrm{Cu} / \mathrm{Al}$. The high catalytic performance of $5 \mathrm{Ni}+1 \mathrm{Gd} / \mathrm{Al}, 5 \mathrm{Ni}+1 \mathrm{Ga} / \mathrm{Al}$, and $5 \mathrm{Ni}+1 \mathrm{Zn} / \mathrm{Al}$ was found to be closely related to their contents of $\mathrm{NiO}$ species, which interacted moderately and strongly with the support, whereas free $\mathrm{NiO}$ in $5 \mathrm{Ni}+1 \mathrm{Cu} / \mathrm{Al}$ made it catalytically inactive, even than $5 \mathrm{Ni} / \mathrm{Al}$. The $5 \mathrm{Ni}+1 \mathrm{Gd} / \mathrm{Al}$ catalyst showed the highest $\mathrm{CH}_{4}$ conversion of $83 \%$ with $\mathrm{H}_{2} / \mathrm{CO}$ mole ratio of $\sim 1.0$.
\end{abstract}

Keywords: methane; dry reforming; mesoporous $\gamma$-alumina; metal oxide promoters; synthesis gas; Ni-based catalyst; Gd-promoted catalyst

\section{Introduction}

The combustion of paraffin hydrocarbons such as methane $\left(\mathrm{CH}_{4}\right)$ yields water and carbon dioxide, which is one of the main contributors to global warming. Efforts have been made for years for converting $\mathrm{CH}_{4}$ and $\mathrm{CO}_{2}$ into highly desired synthesis gas (syngas), composed of hydrogen and carbon monoxide $\mathrm{H}_{2} / \mathrm{CO}$ [1-3]. The reaction of $\mathrm{CH}_{4}$ with $\mathrm{CO}_{2}$ is also known as dry reforming of methane (DRM) [4,5], used along with other types of methane reforming such as steam and oxy-reforming reactions [6]. The usage of the DRM reaction to produce valuable chemicals helps to reduce the harmful impacts of $\mathrm{CO}_{2}$ and $\mathrm{CH}_{4}$ on the environment [7,8]. The $\mathrm{CH}_{4}$ has a much higher global 
warming potential than carbon dioxide [9]. However, DRM is hampered by rapid catalyst deactivation due to carbon deposition and sintering of both the support and the active metal of catalyst [9-11]. The produced hydrogen is widely employed in various industries such as the production of raw chemicals (e.g., methanol and ammonia), fuel cell applications, hydrogenation agent in oil refineries, and reducing gases for the steel industry [4]. DRM includes two main reactions, the reforming of methane (Equation (1)) and the reverse water gas shift (Equation (2)):

$$
\begin{aligned}
\mathrm{CO}_{2}+\mathrm{CH}_{4} & \rightleftharpoons 2 \mathrm{CO}+2 \mathrm{H}_{2} \\
\mathrm{CO}_{2}+\mathrm{H}_{2} & \rightleftharpoons \mathrm{CO}+\mathrm{H}_{2} \mathrm{O}
\end{aligned}
$$

The conventional catalyst used in the DRM reaction is nickel supported on alumina $\left(\mathrm{Ni} / \mathrm{Al}_{2} \mathrm{O}_{3}\right)$ because of its low cost and relatively high catalytic activity [12,13]. Shen et al. [14] investigated Ni-based catalysts supported on different morphologies of alumina (nanosheet, nanofiber, and particle) in the dry reforming of methane. The catalyst with nanosheet morphology displayed superb catalytic activity due to the best docking of Ni nanoparticle on the (110) plane of alumina nanosheet. However, alumina with nanofiber morphology exhibited the best stability due to the confinement of Ni particles within the nest-like structure of alumina nanofiber. Their results indicated that the catalytic performance of DRM was dependent on the morphology of alumina support. However, the $\mathrm{Ni} / \mathrm{Al}_{2} \mathrm{O}_{3}$ is known to deactivate due to the blockage of its active sites by carbon deposition, an issue widely reported in the literature [15,16]. To tackle this problem, coke resistant mesoporous materials are used as supports [8] because of their large surface areas and small or medium pores. Moreover, supports play an important role in the catalytic activity due to their probable chemical effect through their interaction with the active phase. Osman et al. [17] reported that using $\mathrm{Al}_{2} \mathrm{O}_{3}$ support led to better interaction and synergetic effect among the active metal species in the catalyst composition. Mesoporous $\mathrm{Al}_{2} \mathrm{O}_{3}$-supported nickel catalysts exhibited the highest activity, stability, and excellent coke-resistance ability for DRM among several oxide-supported $\mathrm{Ni}$ catalysts [18-20]. The strong interaction between $\mathrm{Ni}$ and mesoporous $\mathrm{Al}_{2} \mathrm{O}_{3}$ improved the dispersion of $\mathrm{Ni}$, retarded its sintering, and improved the adsorption of $\mathrm{CO}_{2}$ because highly dispersed $\mathrm{Ni}$ was very active for the reforming reaction and was less active for carbon deposition via $\mathrm{CH}_{4}$ decomposition. Furthermore, mesoporous supported Ni catalysts were active for the direct activation of $\mathrm{CH}_{4}$ on the surface of supported materials [16]. Al-Fatesh [21] investigated the promotional influence of gadolinium (Gd) on Ni/ $\mathrm{Y}_{2} \mathrm{O}_{3}$ catalyst, employed during the production of $\mathrm{H}_{2}$ from carbon dioxide and methane. It was observed that a small amount of the promoter (1.0 wt. \%) could decrease carbon deposition by $35 \%$ in comparison to the unpromoted one. Carbon dioxide temperature-programmed desorption $\left(\mathrm{CO}_{2}-\mathrm{TPD}\right)$ results showed that $\mathrm{Gd}$-promoted catalysts possessed higher basicity than non-promoted $\mathrm{Ni} / \mathrm{Y}_{2} \mathrm{O}_{3}$ catalyst. In other work, Al-Fatesh et al. [22] investigated the effect of various loadings of gallium promoter of Ni supported on MCM-41 on the activity and stability for the production of syngas by DRM. The addition of gallium generated high surface areas, where $2.5 \mathrm{wt}$. \% of Ga resulted in a surface area of $1036 \mathrm{~m}^{2} / \mathrm{g}$, which was less than that of the unpromoted one $\left(\sim 1133 \mathrm{~m}^{2} / \mathrm{g}\right)$. The addition of Ga reduced both the density of basic sites and the amount of carbon deposition. Weight loss was not recorded for the $3.0 \mathrm{wt}$. $\% \mathrm{Ga}+5.0 \mathrm{wt}$. $\% \mathrm{Ni} / \mathrm{MCM}-41$ sample. The $2.0 \mathrm{wt}$. \% Ga sample displayed $88.2 \%$ conversion of methane and the best stability, while activity declined to only $1.6 \%$ after running the reaction for $400 \mathrm{~min}$ at $800^{\circ} \mathrm{C}$. The promoter increased the ratio of $\mathrm{H}_{2} / \mathrm{CO}$ mole ratio from 0.9 to 1.0. Alternatively, Al-Fatesh et al. [23] studied the influence of Gd promoter in Ni-supported on mesoporous silica (MCM-41) in DRM. The catalytic performance was attained to be significantly enhanced with approximately $0.1 \mathrm{wt}$. \% Gd loading. Thus, Gd can act as a promoter for Ni-based catalysts in DRM reaction. This catalyst (i.e., $0.1 \mathrm{wt}$. \% Gd $+5.0 \mathrm{wt}$. $\% \mathrm{Ni} / \mathrm{MCM}-41$ ) resulted in $>87 \% \mathrm{CH}_{4}$ and $>91 \% \mathrm{CO}_{2}$ conversions and in the production of syngas with $\mathrm{H}_{2} / \mathrm{CO}$ mole ratio nearly equal to one. Mesoporous alumina supported catalyst was designed to allow for Ni dispersion [16]. The investigators decreased the carbon formation by promoting alumina with basic metal oxides. The Ni-based catalysts were able to retard the deactivation by promoting the 
catalyst supports. It was established that $\mathrm{Ni} / \mathrm{MCM}-41$ promoted by rhodium (Rh), prepared via the one-pot procedure, enhanced the stability and activity of the catalyst [24]. Copper $(\mathrm{Cu})$ and cobalt (Co) addition to $\mathrm{Ni} / \mathrm{Al}_{2} \mathrm{O}_{3}-\mathrm{ZrO}_{2}$ catalyst enhanced the surface area, as reflected by BET surface area, especially by cobalt addition, while the $\mathrm{Cu}$ addition made the support particles more compact, and, in general, $\mathrm{Cu}$ and $\mathrm{Co}$ addition improved the conversion, the yields of hydrogen and carbon monoxide, and syngas ratio. The comparison of promoters revealed that the activity of $\mathrm{Co}$ was better than $\mathrm{Cu}$ [25]. The addition of zinc $(\mathrm{Zn})$ to a $\mathrm{Co} / \mathrm{ZrO}_{2}$ catalyst, at a ratio up to $2.0 \mathrm{wt}$. \%, had a positive effect on the catalyst activity and stability, whereas further addition above this limit had the opposite effect. The positive effect of zinc was due to the prevention of Co oxidation by the formation of a Co-Zn alloy [26].

The objective of this study was to determine the optimal promoter for Ni supported on mesoporous $\gamma$-alumina (meso- $\gamma-\mathrm{Al}_{2} \mathrm{O}_{3}$ ) catalyst to maintain great stability and activity, while minimizing the carbon deposition during the DRM process. The effect of promoters such as $\mathrm{Gd}, \mathrm{Ga}, \mathrm{Zn}$, and $\mathrm{Cu}$ on the activity, stability, and coke formation of $\mathrm{Ni} / \mathrm{meso}-\gamma-\mathrm{Al}_{2} \mathrm{O}_{3}$ catalysts was examined. Various characterization techniques were employed to understand the catalytic performance.

\section{Experimental Part}

\subsection{Materials}

Nickel nitrate hexahydrate $\left[\mathrm{Ni}\left(\mathrm{NO}_{3}\right)_{2} \cdot 6 \mathrm{H}_{2} \mathrm{O}, 98 \%\right.$, Alfa Aesar], cupric nitrate trihydrate $\left[\mathrm{Cu}\left(\mathrm{NO}_{3}\right)_{2} \cdot 3 \mathrm{H}_{2} \mathrm{O}\right.$, purum p.a.; $98.0-103 \%$ (RT), Fluka], zinc nitrate hexahydrate $\left[\mathrm{Zn}\left(\mathrm{NO}_{3}\right)_{2} \cdot 6 \mathrm{H}_{2} \mathrm{O}\right.$, 98\%, Alfa Aesar], gallium(III) nitrate hydrate $\left[\mathrm{Ga}\left(\mathrm{NO}_{3}\right)_{3} \cdot \mathrm{xH}_{2} \mathrm{O}, 99.9 \%\right.$ (metal basis), Alfa Aesar], gadolinium(III) nitrate hexahydrate $\left[\mathrm{Gd}\left(\mathrm{NO}_{3}\right)_{3} \cdot 6 \mathrm{H}_{2} \mathrm{O}, 99.9 \%\right.$, Ventron, Alfa Produkte], and mesoporous $\gamma$-alumina (meso- $\gamma-\mathrm{Al}_{2} \mathrm{O}_{3}, 1 / 8$ " pellets, Alfa Aesar) were purchased and were used as received. Ultrapure water was used.

\subsection{Synthesis of Nickel Oxide Supported on Mesoporous- $\gamma-\mathrm{Al}_{2} \mathrm{O}_{3}$ Doped with Metal Oxide}

The catalysts were prepared by the incipient wetness impregnation method, also known as dry impregnation, and the procedure is described as follows. We used this method because when using nickel nitrate as a precursor for nickel, with high concentration, the solution $\mathrm{pH}$ is reduced, and the surface of alumina support is interrupted and is dissolved, which, in turn, creates docking sites for nickel and enables its efficient dispersion onto alumina [27]. On this basis, the required amounts of nickel nitrate hexahydrate to introduce nickel oxide with a weight percentage of $5.0 \mathrm{wt}$. \%, of metal nitrate promoter source to introduce metal oxide promoter with a weight percentage of $1.0 \mathrm{wt}$. \%, and of $m e s o-\gamma-\mathrm{Al}_{2} \mathrm{O}_{3}$ were mixed and were ground together mechanically. Ultrapure water drops were added to the mixture to form a paste, which was stirred mechanically until it was completely dry at room temperature. Drying (at room temperature) and the addition of ultrapure water processes were performed three times to ensure homogeneous distribution within each sample. The samples were then calcined at $600{ }^{\circ} \mathrm{C}$ for three hours under static air, where the temperature was ramped at a rate of $3.0^{\circ} \mathrm{C} \cdot \mathrm{min}^{-1}$. Here and after, the catalysts will be referred as $5 \mathrm{Ni} / \mathrm{Al}$ for non-promoted and $5 \mathrm{Ni}+1 \mathrm{X} / \mathrm{Al}$ $(\mathrm{X}=\mathrm{Cu}, \mathrm{Zn}, \mathrm{Ga}$, or $\mathrm{Gd})$ for promoted catalysts.

\subsection{Catalytic Testing}

DRM experiments were carried out under atmospheric pressure at a reaction temperature of $700{ }^{\circ} \mathrm{C}$. A tubular stainless-steel reactor (i.d., $9.0 \mathrm{~mm}$; length, $300 \mathrm{~mm}$ ) was used. An amount of $0.1 \mathrm{~g}$ of the catalyst was placed between two quartz wool beds to perform the activity test. Temperature measurement, during the reaction, was measured by K-type thermocouple, which was placed axially at the center of the catalyst bed. Before the reaction, the catalysts were reduced at $600{ }^{\circ} \mathrm{C}$ with the flow of $\mathrm{H}_{2}$ for an hour at a flow rate of $30.0 \mathrm{~mL} / \mathrm{min}$. During the experiments, the mixture of methane, carbon dioxide and nitrogen in a 3:3:1 volume ratio was used as feed gas, having space velocity of $2990 \mathrm{~h}^{-1}$. The effluent gas was analyzed by an on-line GC (GC-2014 Shimadzu Corp., Kyoto, Japan), 
equipped with a thermal conductivity detector (TCD) and two columns: Porapak Q and Molecular Sieve 5A. This GC was connected in series/bypass connections in order to have a complete analysis of the reaction products. The methane conversion and hydrogen yield were calculated:

$$
\begin{gathered}
\mathrm{CH}_{4} \text { conversion }(\%)=\frac{\mathrm{CH}_{4, \text { in }}-\mathrm{CH}_{4, \text { out }}}{\mathrm{CH}_{4, \text { in }}} \times 100 \\
\mathrm{CO}_{2} \text { conversion }(\%)=\frac{\mathrm{CO}_{2, \text { in }}-\mathrm{CO}_{2, \text { out }}}{\mathrm{CO}_{2, \text { in }}} \times 100 \\
\mathrm{H}_{2} \text { yield }(\%)=\frac{\mathrm{H}_{2, \text { out }}}{2 \times \mathrm{CH}_{4, \text { in }}} \times 100 \\
\frac{\mathrm{H}_{2}}{\mathrm{CO}}=\frac{\text { mole of } \mathrm{H}_{2} \text { produced }}{\text { mole of } \mathrm{CO} \text { produced }}
\end{gathered}
$$

Deactivation Factor $(\%)=\frac{\text { Initial } \mathrm{CH}_{4} \text { Conversion }- \text { Final } \mathrm{CH}_{4} \text { Conversion }}{\text { Initial } \mathrm{CH}_{4} \text { Conversion }} \times 100$

\subsection{Catalyst Characterization}

\subsection{1. $\mathrm{N}_{2}$ Physisorption}

The Pore size distribution and the surface area of the catalysts were determined by physisorption of nitrogen at $-196{ }^{\circ} \mathrm{C}$ by using a Micromeritics Tristar II 3020 surface area and porosity analyzer. The distribution of the pore size was calculated by Barrett, Joyner, and Halenda (BJH) method.

\subsubsection{XRD}

Rigaku (Miniflex) diffractometer, with a $\mathrm{Cu} \mathrm{K} \alpha$ X-ray radiation working at $40 \mathrm{kV}$ and $40 \mathrm{~mA}$, was used to examine the structure of the catalysts before and after the reaction. A step of $0.02^{\circ}$ and scanning $2 \theta$ range of $10-85^{\circ}$ were used. $X^{\prime}$ Pert high score plus software was used to evaluate the data obtained from the instrument. Different phases were matched to the JCPDS data bank. The result of the XRD analysis (Figure S1) is discussed in the supplementary file.

\subsubsection{TPR}

A sample of $70 \mathrm{mg}$ was put in the TPR cell of a Micromeritics Auto Chem II apparatus. Then the furnace temperature was increased from room temperature to $1000{ }^{\circ} \mathrm{C}$ with heating rate of $10^{\circ} \mathrm{C} \cdot \mathrm{min}^{-1}$, under $40 \mathrm{~mL} \cdot \mathrm{min}^{-1}$ flow of 10 vol. $\% \mathrm{H}_{2} /$ Ar mixture. The $\mathrm{H}_{2}$ consumption was monitored by a TCD unit.

\subsubsection{Temperature-Programmed Oxidation (TPO)}

TPO is a useful technique for describing the type of carbon deposit over the surface of the catalyst. With respect to the literature, formed carbon, over the surface of catalysts in $\mathrm{CO}_{2}$ reforming of methane, occurs in various forms: graphitic, amorphous, and atomic [28]. Under oxidative medium and high temperature, deposited carbon can be oxidised to carbon dioxide. The carbon oxidation below $250{ }^{\circ} \mathrm{C}$ is called atomic carbon, while the carbon which oxidised in the range of $250-600{ }^{\circ} \mathrm{C}$ was categorized as amorphous, whereas graphitic carbon burned above $600{ }^{\circ} \mathrm{C}$ [28]. To this end, the TPO was performed under $10 \% \mathrm{O}_{2} / \mathrm{He}$ atmosphere for identifying the form of deposited carbon on the surface of the catalyst by using a Micromeritics AutoChem II (Micromeritics, Atlanta, GA, USA). The analysis was performed in the temperature range of $50-800{ }^{\circ} \mathrm{C}$, under a flow of $40 \mathrm{~mL} / \mathrm{min}$ of $10 \% \mathrm{O}_{2} / \mathrm{He}$. The spent catalyst was pre-treated under argon atmosphere at $150{ }^{\circ} \mathrm{C}$ for half an hour and the temperature was then reduced to $25^{\circ} \mathrm{C}$. 


\subsubsection{Thermo-Gravimetric Analysis (TGA)}

The TGA was carried out under air flow at $50 \mathrm{~mL} / \mathrm{min}$, using a TGA-15 SHIMADZU analyser, to determine the amount of carbon deposited on the catalyst surface after the reaction, where 10-15 $\mathrm{mg}$ of the spent catalyst was filled into a platinum pan of the thermo-balance. Then, the temperature was increased to $1000{ }^{\circ} \mathrm{C}$ at a heating rate of $20^{\circ} \mathrm{C} \cdot \mathrm{min}^{-1}$, and the weight reduction was determined.

\subsubsection{Laser Raman (NMR-4500) Spectrometer}

Laser Raman (NMR-4500) Spectrometer (JASCO, Japan) was used to record Raman spectra of the spent catalyst samples. The wavelength of the excitation beam was set to $532 \mathrm{~nm}$, and objective lens of $100 \times$ magnification was used for the measurement. The laser intensity was adjusted to $1.6 \mathrm{~mW}$. Each spectrum was received by averaging 3 exposures on 10 seconds. Spectra were recorded in the range $1200-3000 \mathrm{~cm}^{-1}$ (Raman shift) and were processed by using Spectra Manager Ver.2 software (JASCO, Japan).

\section{Results and Discussion}

\subsection{BET (Brunauer-Emmett-Teller) and the BJH (Barrett, Joyner, and Halenda) analyses}

These analyses provided the specific surface areas $\left(\mathrm{S}_{\mathrm{BET}}\right)$, pore volume $\left(\mathrm{V}_{\mathrm{P}}\right)$, and average pore diameter $\left(d_{p}\right)$, depending on promoter identity. Table 1 displays the $S_{B E T}, V_{P}$, and $d_{p}$ values for all the catalysts investigated in this work.

Table 1. Textural properties $\left(\mathrm{S}_{\mathrm{BET}}, \mathrm{V}_{\mathrm{P}}, \mathrm{d}_{\mathrm{p}}\right)$ of the non-promoted and promoted catalysts.

\begin{tabular}{cccc}
\hline Catalyst & $\mathbf{S}_{\mathbf{B E T}}, \mathbf{~ m}^{\mathbf{2}} \cdot \mathbf{g}^{\mathbf{- 1}}$ & $\mathbf{V}_{\mathbf{P}}, \mathbf{c m}^{\mathbf{3}} \cdot \mathbf{g}^{\mathbf{- 1}}$ & $\mathbf{d}_{\mathbf{p}}, \mathbf{n m}$ \\
\hline $5 \mathrm{NiAl}$ & 182 & 0.61 & 11.3 \\
$5 \mathrm{Ni}+1 \mathrm{Cu} / \mathrm{Al}$ & 185 & 0.59 & 11.4 \\
$5 \mathrm{Ni}+1 \mathrm{Zn} / \mathrm{Al}$ & 187 & 0.60 & 11.4 \\
$5 \mathrm{Ni}+1 \mathrm{Ga} / \mathrm{Al}$ & 185 & 0.61 & 11.3 \\
$5 \mathrm{Ni}+1 \mathrm{Gd} / \mathrm{Al}$ & 193 & 0.62 & 11.4 \\
\hline
\end{tabular}

Promoter loading of $1.0 \mathrm{wt}$. \% did not affect $\mathrm{V}_{\mathrm{P}}$ and $\mathrm{P}_{\mathrm{d}}$. The $\mathrm{S}_{\mathrm{BET}}$ parameter was not also affected by the promoter type except in the case of Gd promoter, which led to a slight increase in $S_{B E T}$ in comparison with non-promoted catalyst. Nitrogen adsorption-desorption isotherms (Figure 1) showed that all prepared catalysts had a mesoporous structure. The catalysts displayed type IV isotherm with a hysteresis loop of the H3-type, resulting from capillary condensation and evaporation at high relative pressures. This structural feature indicated the mesoporous structure of the $\gamma-\mathrm{Al}_{2} \mathrm{O}_{3}$ support with hexagonal array. There was no significant change in the framework of the support due to the loading of the promoter. The isotherms of the catalysts had a strongly noticeable increase in the relative pressure region of $0.65-0.95$ due to combination of $\mathrm{N}_{2}$ capillary condensation in the mesopore and the condensation of $\mathrm{N}_{2}$ in the interstitial cavities of the support. 


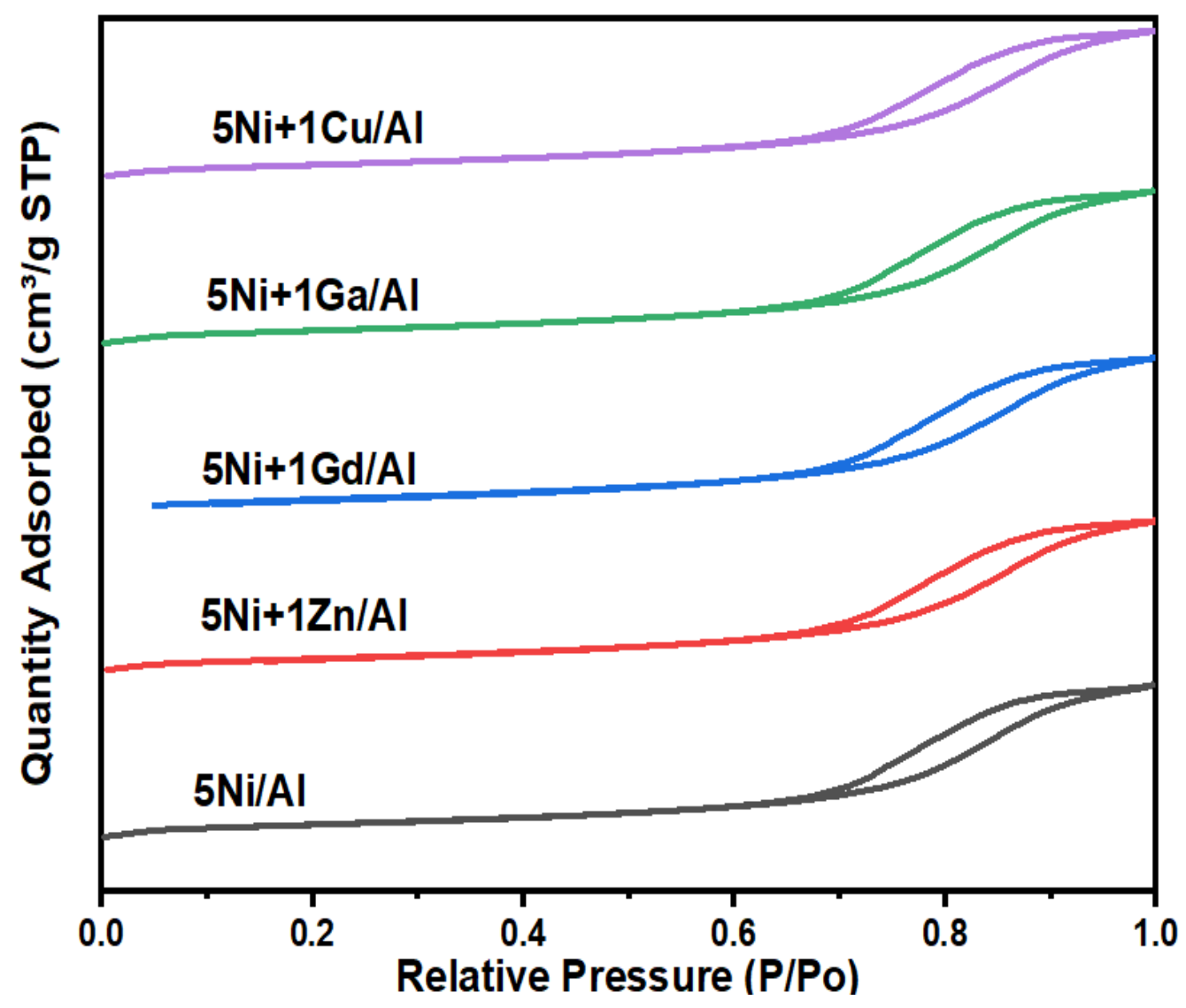

Figure 1. $\mathrm{N}_{2}$ adsorption-desorption isotherms for non-promoted and promoted catalysts.

\subsection{Temperature-Programmed Reduction (TPR)}

The $\mathrm{H}_{2}$-TPR was used to study the ease and extent of reducibility of the fresh catalysts. The reduction peaks as a function of temperature are shown in Figure 2. Reduction peaks were detected below $800{ }^{\circ} \mathrm{C}$. The different reduction temperature regions were due to the interaction strength between $\mathrm{NiO}$ and supports. The meso- $\gamma-\mathrm{Al}_{2} \mathrm{O}_{3}$ support showed no reduction peaks in TPR measurement [29]. Three reduction peaks were detected for promoted catalysts, whereas two peaks were detected for the non-promoted catalyst. The first peak, in the temperature range of $200-300{ }^{\circ} \mathrm{C}$, was quite close to the reduction temperature of bulk $\mathrm{NiO}$, which indicated that this kind of $\mathrm{NiO}$ had no interaction with the support. The second peak, in the temperature range of $500-600^{\circ} \mathrm{C}$, indicated moderate interaction with the support, while the third peak, in the temperature range of $700-800{ }^{\circ} \mathrm{C}$, showed strong interaction of $\mathrm{NiO}$ with the mesoporous $\gamma-\mathrm{Al}_{2} \mathrm{O}_{3}$, as $\mathrm{NiAl}_{2} \mathrm{O}_{4}$ was being formed [30]. This strong interaction improved the dispersion of $\mathrm{Ni}$ and hindered its sintering during the DRM. The broadening of the last peak could be attributed to the reduction of $\mathrm{Ni}$ ion situated at different layers in the pore wall [25], thus emphasizing the intense interaction between the $\mathrm{NiO}$ particles and the support. The non-promoted catalyst $5 \mathrm{Ni} / \mathrm{Al}$ had reduction peaks for $\mathrm{NiO}$ that strongly interacted with support in the temperature range of $700-800{ }^{\circ} \mathrm{C}$. The $5 \mathrm{Ni}+1 \mathrm{Cu} / \mathrm{Al}$ catalyst had reduction peaks for free $\mathrm{NiO}$ additionally at $300{ }^{\circ} \mathrm{C}$. The rest of the catalysts (i.e., $5 \mathrm{Ni}+1 \mathrm{Zn} / \mathrm{Al}, 5 \mathrm{Ni}+1 \mathrm{Ga} / \mathrm{Al}$, and $5 \mathrm{Ni}+1 \mathrm{Gd} / \mathrm{Al}$ ) had reduction peaks for $\mathrm{NiO}$ moderately and strongly interacted with the support. The $5 \mathrm{Ni}+1 \mathrm{Gd} / \mathrm{Al}$ catalyst had a higher intensity of both types of $\mathrm{NiO}$ than $5 \mathrm{Ni}+1 \mathrm{Zn} / \mathrm{Al}$ and $5 \mathrm{Ni}+1 \mathrm{Ga} / \mathrm{Al}$ catalysts. The $5 \mathrm{Ni} / \mathrm{Al}$ showed the highest peak at $700-800{ }^{\circ} \mathrm{C}$ for all catalysts and no apparent peaks at low temperatures, justifying its requirement for high reduction temperature and low tendency to react with hydrogen. The negative peaks below $200{ }^{\circ} \mathrm{C}$ in the TPR profiles are due to the hydrogen spillover into the mesopores of the catalysts, as we reported in our previous publication [31]. 


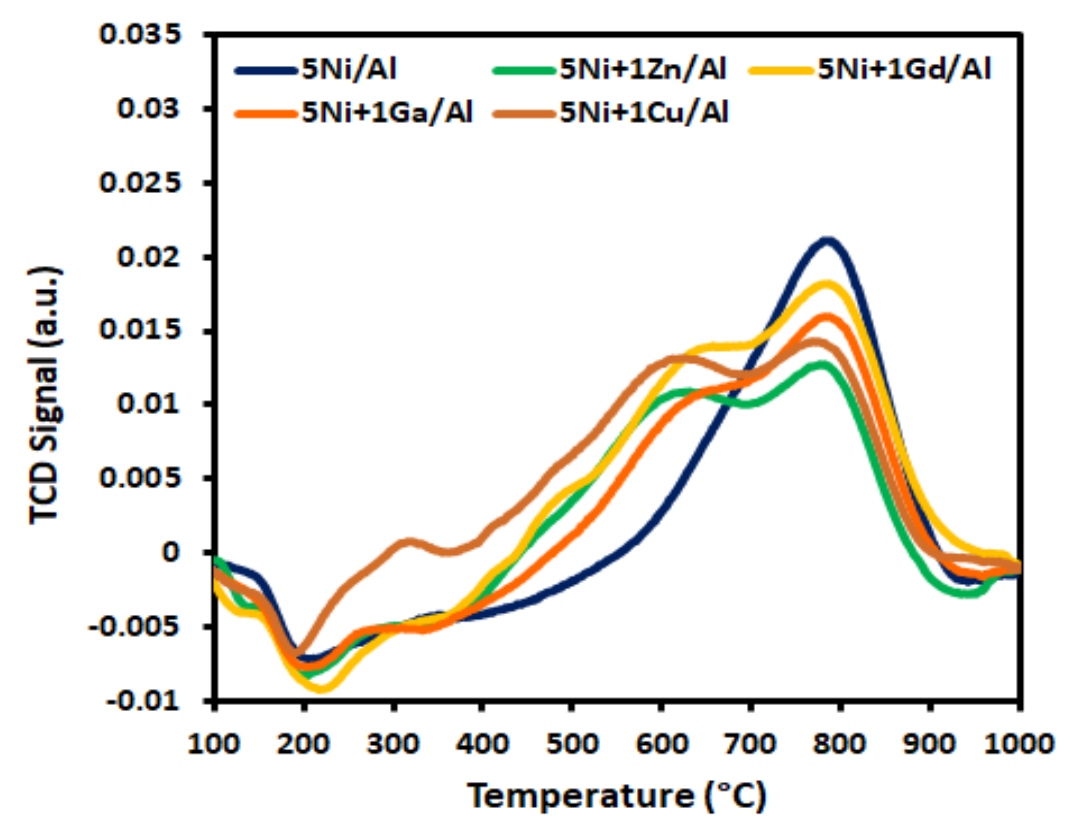

Figure 2. Temperature-programmed reduction (TPR) profiles of the non-promoted and promoted catalysts.

\subsection{Catalytic Activity}

Figure $3 \mathrm{~A}, \mathrm{~B}$ shows the conversions of $\mathrm{CH}_{4}$ and $\mathrm{CO}_{2}$ along the time-on-stream (TOS). The catalysts were highly stable at the reaction temperature of $700{ }^{\circ} \mathrm{C}$ during the reaction time of $460 \mathrm{~min}$, as shown in Figure 3. The $\mathrm{CH}_{4}$ and $\mathrm{CO}_{2}$ conversions of the catalyst system were found in order of $5 \mathrm{Ni}+1 \mathrm{Gd} / \mathrm{Al}$ $>5 \mathrm{Ni}+1 \mathrm{Ga} / \mathrm{Al}>5 \mathrm{Ni}+1 \mathrm{Zn} / \mathrm{Al}>5 \mathrm{Ni} / \mathrm{Al}>5 \mathrm{Ni}+1 \mathrm{Cu} / \mathrm{Al}$. The catalytic performances of the first three catalysts were found to correlate with the content of $\mathrm{NiO}$, which interacted moderately and strongly with the support, as shown in the $\mathrm{H}_{2}$-TPR result above. The $\mathrm{H}_{2} / \mathrm{CO}$ mole ratio over these catalysts were also close to 1.0 (Table 2). It hinted towards suppression of reverse water gas shift reaction $\left(\mathrm{CO}_{2}+\mathrm{H}_{2}\right.$ $\rightarrow \mathrm{CO}+\mathrm{H}_{2} \mathrm{O}$ ) over these catalyst systems. The $5 \mathrm{Ni}+1 \mathrm{Gd} / \mathrm{Al}$ catalyst was found to be the most stable and resulted in the highest conversions of $\mathrm{CH}_{4}(\sim 83 \%)$ and $\mathrm{CO}_{2}$ and $(\sim 89 \%)$ with the highest activity for producing syngas because of its higher oxygen storage capacity [23]. The calculated deactivation factors (DF) were shown in Table 2 below, with the lowest DF for the $5 \mathrm{Ni}+1 \mathrm{Gd} / \mathrm{Al}$ catalyst. $\mathrm{The}_{2} / \mathrm{CO}$ molar ratio versus TOS is shown in Figure 3C. The presence of free $\mathrm{NiO}$ (as shown in $\mathrm{H}_{2}$-TPR) in $5 \mathrm{Ni}+1 \mathrm{Cu} / \mathrm{Al}$ caused less catalytic performance even than the non-promoted catalyst $5 \mathrm{Ni} / \mathrm{Al}$. Low $\mathrm{H}_{2} / \mathrm{CO}$ ratio for both catalysts may be due to the dominance of reverse water gas shift reaction.

Table 2. Conversion of $\mathrm{CH}_{4}, \mathrm{H}_{2} / \mathrm{CO}$ ratio and deactivation factor (DF) for non-promoted and promoted catalysts.

\begin{tabular}{|c|c|c|c|c|c|}
\hline Catalyst & $\begin{array}{c}\mathrm{X}_{\mathrm{i}}\left(\mathrm{CH}_{4}\right) \\
\%\end{array}$ & $\begin{array}{c}\mathrm{X}_{\mathrm{f}}\left(\mathrm{CH}_{4}\right) \\
\%\end{array}$ & $\begin{array}{c}\mathrm{H}_{2} / \mathrm{CO} \text { Mole } \\
\text { Ratio }^{a}\end{array}$ & $\begin{array}{c}\mathrm{DF}^{\mathbf{b}} \\
\%\end{array}$ & $\begin{array}{c}\text { Coke }^{c} \\
\text { \%wt Loss }\end{array}$ \\
\hline $5 \mathrm{Ni} / \mathrm{Al}$ & 79.3 & 78.6 & 0.97 & 0.90 & 4.0 \\
\hline $5 \mathrm{Ni}+1 \mathrm{Cu} / \mathrm{Al}$ & 77.4 & 76.1 & 0.97 & 1.70 & 5.8 \\
\hline $5 \mathrm{Ni}+1 \mathrm{Zn} / \mathrm{Al}$ & 80.0 & 79.4 & 1.00 & 0.75 & 4.8 \\
\hline $5 \mathrm{Ni}+1 \mathrm{Ga} / \mathrm{Al}$ & 79.0 & 78.7 & 0.99 & 0.38 & 5.5 \\
\hline $5 \mathrm{Ni}+1 \mathrm{Gd} / \mathrm{Al}$ & 83.4 & 83.2 & 1.00 & 0.24 & 6.5 \\
\hline
\end{tabular}

a Average ratio; ${ }^{\mathrm{b}}$ Deactivation factor $(\mathrm{DF})=\left[\left(\right.\right.$ initial $\mathrm{CH}_{4}$ conversion - final $\mathrm{CH}_{4}$ conversion $) /$ initial $\mathrm{CH}_{4}$ conversion $]$ $\times 100$; ${ }^{c}$ Coke Estimated using TGA data. 

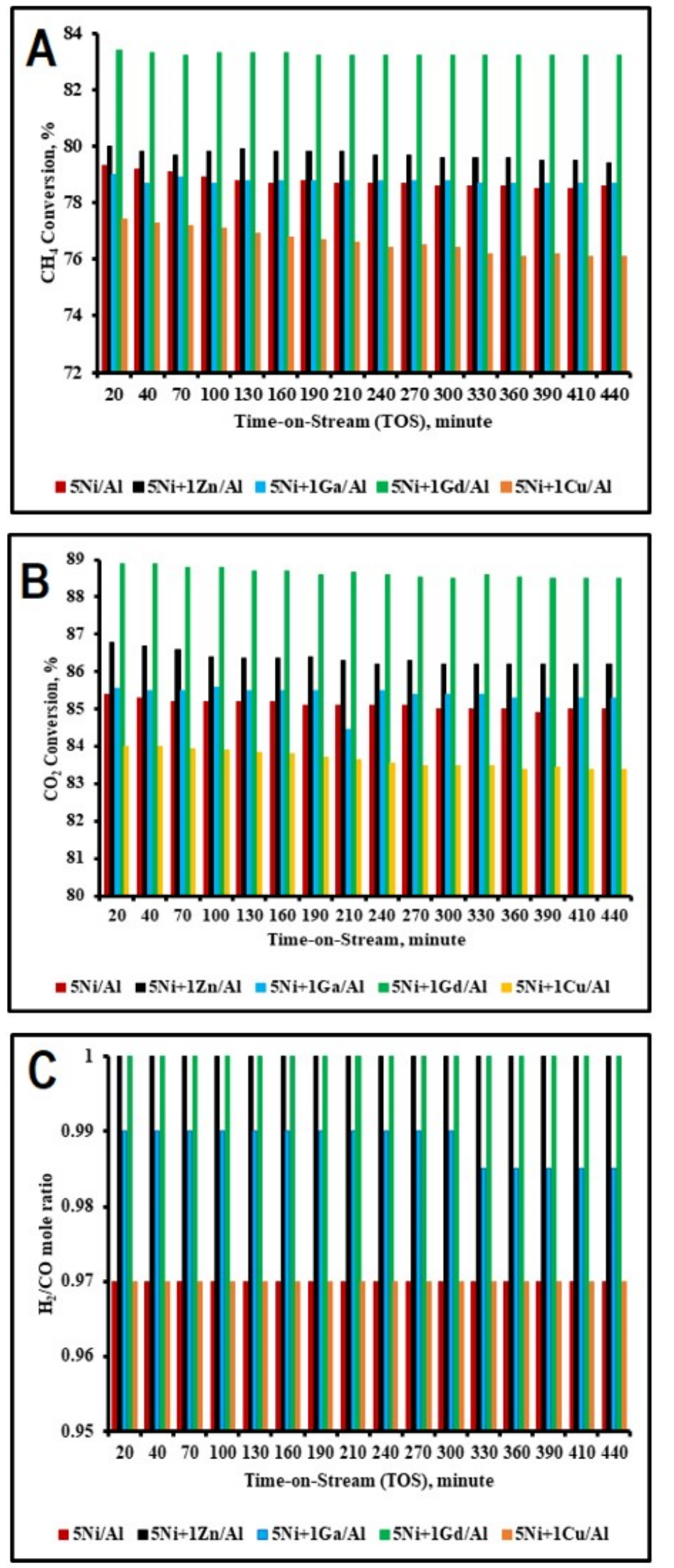

Figure 3. (A) Conversion of $\mathrm{CH}_{4}$, (B) Conversion of $\mathrm{CO}_{2}$, and (C) the fraction of $\mathrm{H}_{2} / \mathrm{CO}$ at $700{ }^{\circ} \mathrm{C}, 1.0$ atm and GHSV $=2990 \mathrm{~h}^{-1}$. 


\subsection{Temperature Programmed Oxidation (TPO)}

TPO is a useful characterization technique for the analysis of the kind of carbon deposits on the surface of spent catalysts. As mentioned before, carbon deposits on the spent catalysts could be graphitic, amorphous, or atomic in nature, depending on the temperature of oxidation. It has been reported that carbon that oxidizes below $250{ }^{\circ} \mathrm{C}$ is atomic in nature, while carbon that oxidizes between 250-600 ${ }^{\circ} \mathrm{C}$ falls under the category of amorphous. Lastly, graphitic carbon oxidizes at a temperature above $600{ }^{\circ} \mathrm{C}[28]$.

The TPO showed peaks that correspond to the kind of carbon formed on the catalyst surface. The TPO curves for all the spent catalysts had higher intensity peaks appearing below $250{ }^{\circ} \mathrm{C}$ (Figure 4 ), corresponding to less ordered (more reactive) atomic carbon [32-34]. The negative peaks that appeared at around $400{ }^{\circ} \mathrm{C}$ indicate oxidation of the metals. A small positive peak can be seen at around $400{ }^{\circ} \mathrm{C}$ for all the used catalysts except $5 \mathrm{Ni}+1 \mathrm{Zn} / \mathrm{Al}$. This is an indication of the presence of amorphous carbon on these catalysts. Moreover, there appeared to be very small deposits of graphitic carbon on the spent $5 \mathrm{Ni}+1 \mathrm{Ga} / \mathrm{Al}$ and $5 \mathrm{Ni}+1 \mathrm{Cu} / \mathrm{Al}$, which can be ascribed to the peaks appearing at above $600{ }^{\circ} \mathrm{C}$.

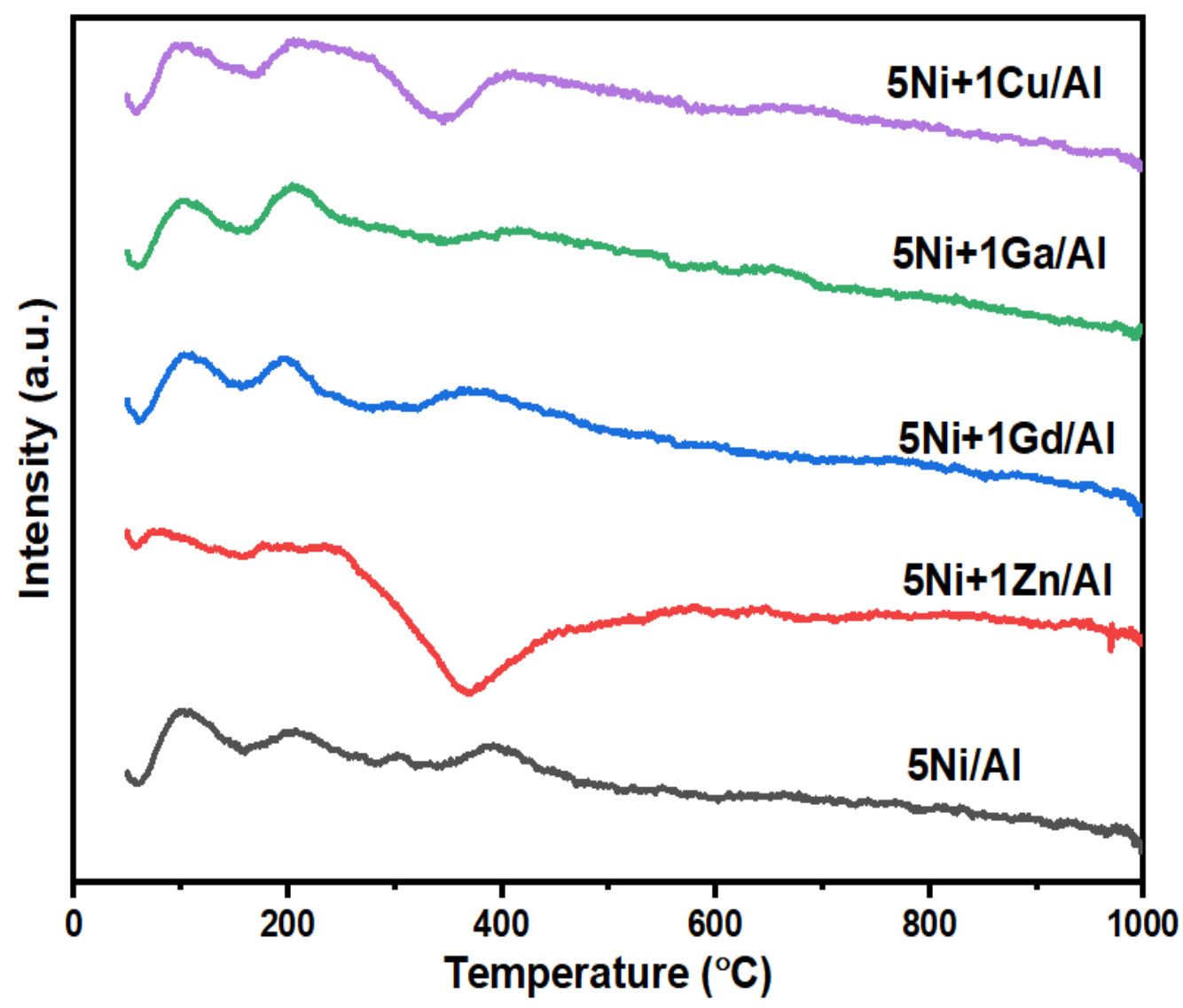

Figure 4. Temperature programmed oxidation (TPO) profiles of the used catalysts.

\subsection{Thermogravimetric analysis (TGA) of Spent Catalyst}

The profiles of the five spent catalysts showed weight losses of $3.0 \mathrm{wt}$. \%, $5.0 \mathrm{wt}$. \%, $4.0 \mathrm{wt}$. $\%, 4.0 \mathrm{wt}$. $\%$, and $2.0 \mathrm{wt}$. \% for $5 \mathrm{Ni}+1 \mathrm{Cu} / \mathrm{Al}, 5 \mathrm{Ni}+1 \mathrm{Gd} / \mathrm{Al}, 5 \mathrm{Ni}+1 \mathrm{Zn} / \mathrm{Al}$, and $5 \mathrm{Ni} / \mathrm{Al}$, respectively (Figure 5). All the spent catalysts were studied after catalytic cycle at $700{ }^{\circ} \mathrm{C}$ during $460 \mathrm{~min}$ on stream. The $5 \mathrm{Ni}+1 \mathrm{Gd} / \mathrm{Al}$ had the highest carbon content due to high methane conversion into syngas and its decomposition into carbon. The catalyst probably did not do much in gasifying the carbon deposits, indicating its ability to accumulate carbon deposits compared to the other catalysts. On the other hand, $5 \mathrm{Ni} / \mathrm{Al}$ showed the least carbon content. 


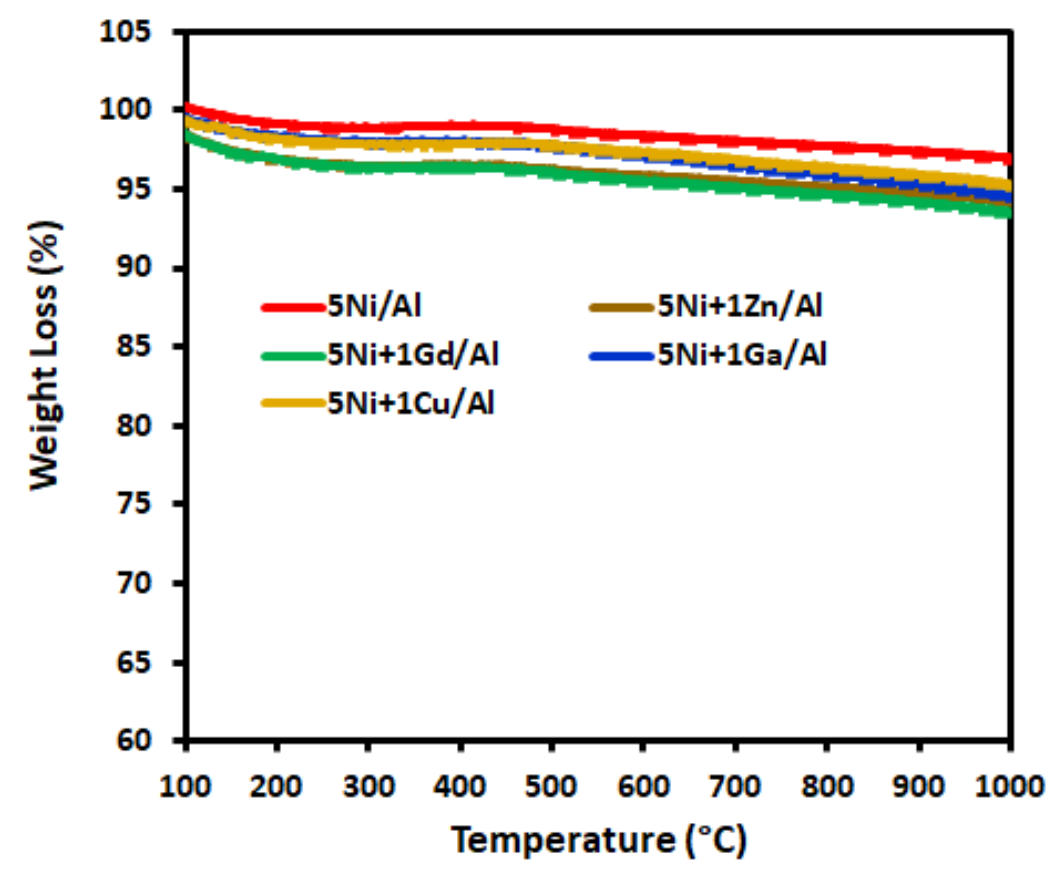

Figure 5. Thermogravimetric analysis (TGA) curves of the spent catalysts.

\subsection{Scanning Electron Microscope (SEM)}

The SEM images of all samples are shown in Figure 6. The morphology of all the catalyst samples were more or less the same. All the catalysts showed agglomerated particles with undefined shapes, where the identity of the promoter had no effect on the morphology.
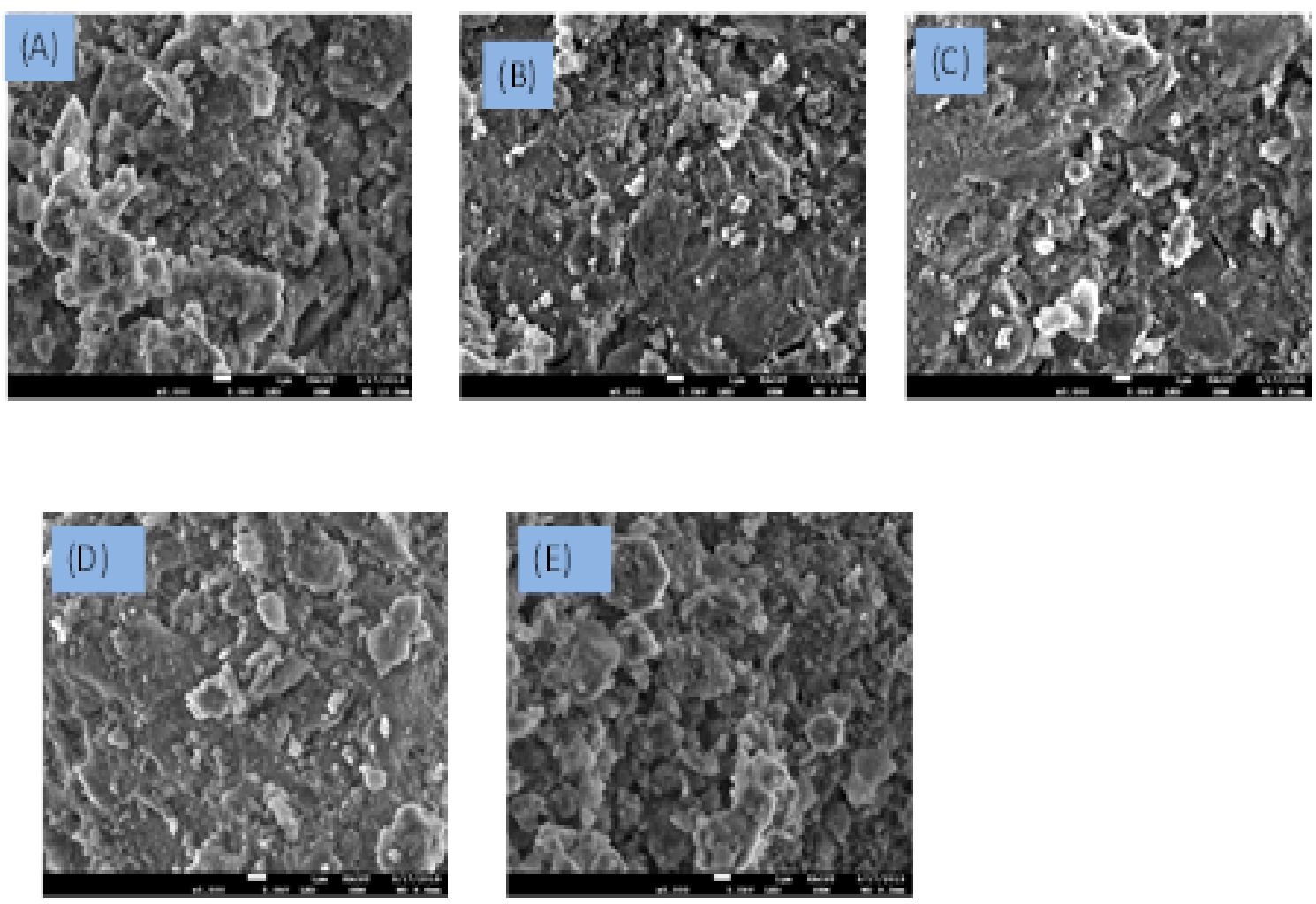

Figure 6. SEM images of the fresh catalysts (A) $5 \mathrm{Ni} / \mathrm{Al}$, (B) $5 \mathrm{Ni}+1 \mathrm{Gd} / \mathrm{Al}$, (C) $5 \mathrm{Ni}+1 \mathrm{Zn} / \mathrm{Al}$, (D) $5 \mathrm{Ni}+1 \mathrm{Cu} / \mathrm{Al}$, and $(\mathrm{E}) 5 \mathrm{Ni}+1 \mathrm{Ga} / \mathrm{Al}$. 


\subsection{Raman Analysis}

On the Raman spectra of all the spent catalysts (Figure 7), there are two bands with Raman shifts: $1474 \pm 5 \mathrm{~cm}^{-1}$ and $1537 \pm 10 \mathrm{~cm}^{-1}$, which correspond to the D and G band, respectively. The D band can be ascribed to carbon deposits with imperfect structures that are disordered (amorphous), while the $G$ band is a characteristic of well-ordered carbon structure (graphitic) [35-37]. The $I_{D} / I_{G}$ ratio showed that the spent $5 \mathrm{Ni} / \mathrm{Al}$ had the highest disordered (amorphous) carbon on its surface after the reaction, while this ratio decreased for the promoted catalysts, indicating that the presence of promoters caused a good order of carbon deposits (graphitic). This conclusion about the deposited carbon on the surface of the spent catalysts from Raman spectra was in parallel with the results of their corresponding TPO analysis.

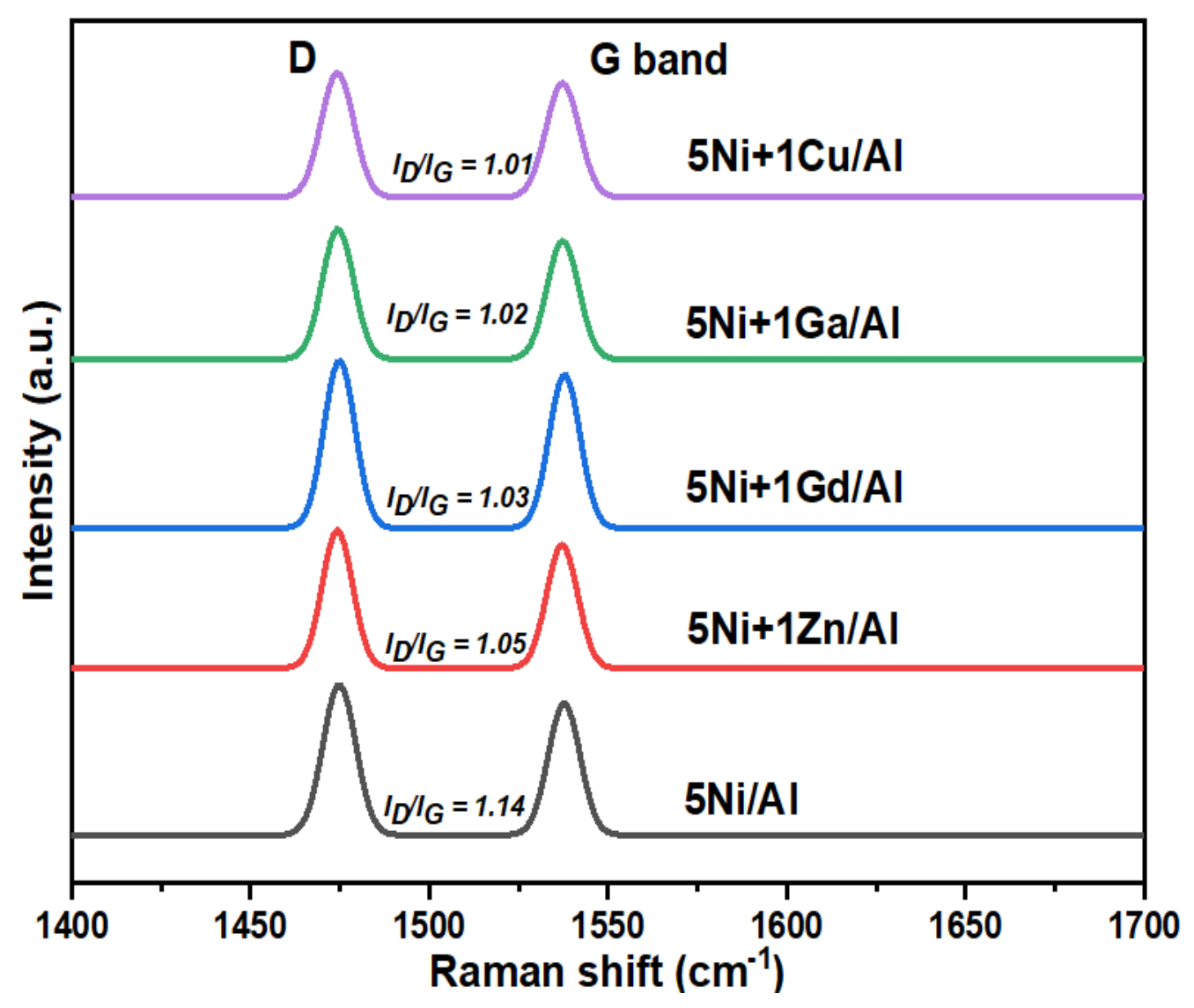

Figure 7. Raman spectra for the spent catalysts.

\section{Conclusions}

The $\mathrm{N}_{2}$ physisorption analysis confirmed the mesoporosity of the prepared catalysts. In the TPR analysis, an extra peak was observed owing to the promoting effects. In the XRD analysis, no peaks related to promoters were detected, and hence, they scattered well in the matrix of the catalyst. The TPO analysis depicted the presence of atomic carbon, some amorphous and graphitic carbon, as well as the oxidation of the metals. The TGA analysis indicated a similar amount of carbon deposition for all the spent catalyst. The SEM analysis displayed agglomerated particles with undefined shapes. Promoters with 1.0 wt. \% loading $\left(\mathrm{CuO}, \mathrm{ZnO}, \mathrm{Ga}_{2} \mathrm{O}_{3}\right.$, or $\left.\mathrm{Gd}_{2} \mathrm{O}_{3}\right)$ were used for enhancing the catalytic performance of $5 \mathrm{Ni} / \mathrm{Al}$ in DRM. The $\mathrm{CH}_{4}$ and $\mathrm{CO}_{2}$ conversions increased in the order of $5 \mathrm{Ni}+1 \mathrm{Cu} / \mathrm{Al}$ $<5 \mathrm{Ni} / \mathrm{Al}<5 \mathrm{Ni}+1 \mathrm{Zn} / \mathrm{Al}<5 \mathrm{Ni}+1 \mathrm{Ga} / \mathrm{Al}<5 \mathrm{Ni}+1 \mathrm{Gd} / \mathrm{Al}$. The catalytic performance of $5 \mathrm{Ni}+1 \mathrm{Gd} / \mathrm{Al}$, $5 \mathrm{Ni}+1 \mathrm{Ga} / \mathrm{Al}$, and $5 \mathrm{Ni}+1 \mathrm{Zn} / \mathrm{Al}$ were found to correlate with the content of the $\mathrm{NiO}$, which interacts moderately and strongly with support. Free $\mathrm{NiO}$ species in $5 \mathrm{Ni}+1 \mathrm{Cu} / \mathrm{Al}$ made its catalytic performance 
even inferior to that of $5 \mathrm{Ni} / \mathrm{Al}$. $5 \mathrm{Ni}+1 \mathrm{Gd} / \mathrm{Al}$ showed the highest conversions of $\mathrm{CH}_{4}(\sim 83 \%)$ and $\mathrm{CO}_{2}$ ( $\sim 89 \%)$ with $\mathrm{H}_{2} / \mathrm{CO}$ mole ratio of $\sim 1.0$.

Supplementary Materials: The following are available online at http://www.mdpi.com/2227-9717/8/5/522/s1, Figure S1: XRD patterns of non-promoted and promoted catalysts.

Author Contributions: Experiment, A.S.A.-F., M.S.L., and S.O.K., writing-original draft preparation, A.S.A.-F., A.A.B., A.A.I., A.H.F., M.S.L., A.Y.E., and S.O.K.; preparation of catalyst, A.A., A.A.B., and R.A., writing-review and editing, A.A.B., A.E.A., A.I.O., A.S.A.-F., and A.H.F. All authors have read and agreed to the published version of the manuscript.

Funding: Funding: The work is supported by the Deanship of Scientific Research programs of King Saud University via project No. RGP-1435-078.

Acknowledgments: The KSU authors would like to extend their sincere appreciation to the Deanship of Scientific Research at the King Saud University for funding this research group project \# No. RGP-1435-078. The author would like to thank Charlie Farrell who assisted in the proof-reading of the manuscript.

Conflicts of Interest: The authors declare no conflict of interest.

\section{References}

1. Aghamohammadi, S.; Haghighi, M.; Karimipour, S. A Comparative Synthesis and Physicochemical Characterizations of $\mathrm{Ni} / \mathrm{Al}_{2} \mathrm{O}_{3}-\mathrm{MgO}$ Nanocatalyst via Sequential Impregnation and Sol-Gel Methods Used for $\mathrm{CO}_{2}$ Reforming of Methane. J. Nanosci. Nanotechnol. 2013, 13, 4872-4882. [CrossRef]

2. Fan, M.-S.; Abdullah, A.Z.; Bhatia, S. Hydrogen production from carbon dioxide reforming of methane over $\mathrm{Ni}-\mathrm{Co} / \mathrm{MgO}-\mathrm{ZrO}_{2}$ catalyst: Process optimization. Int. J. Hydrog. Energy 2011, 36, 4875-4886. [CrossRef]

3. $\mathrm{Xu}, \mathrm{L} . ;$ Song, $\mathrm{H}$.; Chou, L. Mesoporous nanocrystalline ceria-zirconia solid solutions supported nickel based catalysts for $\mathrm{CO}_{2}$ reforming of $\mathrm{CH}_{4}$. Int. J. Hydrog. Energy 2012, 37, 18001-18020. [CrossRef]

4. Batiot-Dupeyrat, C.; Valderrama, G.; Meneses, A.; Martinez, F.; Barrault, J.; Tatibouët, J.M. Pulse study of $\mathrm{CO}_{2}$ reforming of methane over LaNiO3. Appl. Catal. A Gen. 2003, 248, 143-151. [CrossRef]

5. Gallego, G.S.; Batiot-Dupeyrat, C.; Barrault, J.; Florez, E.; Mondragón, F. Dry reforming of methane over $\mathrm{LaNi1}-\mathrm{yByO} \pm \delta(\mathrm{B}=\mathrm{Mg}, \mathrm{Co})$ perovskites used as catalyst precursor. Appl. Catal. A Gen. 2008, 334, 251-258. [CrossRef]

6. Osman, A.I. Catalytic Hydrogen Production from Methane Partial Oxidation: Mechanism and Kinetic Study. Chem. Eng. Technol. Accept. 2020. [CrossRef]

7. Sutthiumporn, K. Development of Nickel Based Catalystssynthesized over Different Precursors for Dry $\mathrm{CO}_{2}$ Reforming of Methane to Syngas Production. Master's Thesis, National University of Singapore, Singapore, 2011; pp. 7-10. Available online: https://core.ac.uk/download/pdf/48655900.pdf (accessed on 28 February 2020).

8. Zhan, H.-J.; Shi, X.-Y.; Huang, X.; Zhao, N. Highly coke-resistant ordered mesoporous Ni/SiC with large surface areas in $\mathrm{CO}_{2}$ reforming of $\mathrm{CH}_{4}$. J. Fuel Chem. Technol. 2019, 47, 942-948. [CrossRef]

9. Fakeeha, A.H.; Al-Fatesh, A.S.; Ibrahim, A.A.; Abasaeed, A.E. Effect of Calcium Promoter on Ni-Based Catalysts Supported on $\alpha-\mathrm{Al}_{2} \mathrm{O}_{3}$ and $\mathrm{TiO}_{2}-\mathrm{P} 25$. Appl. Mech. Mater. 2012, 204-208, 3909-3913. [CrossRef]

10. Al-Fatesh, A.S.A.; Ibrahim, A.A.; Fakeeha, A.H.; Abasaeed, A.E. Activity and Carbon Formation of a Low Ni-Loading Alumina-Supported Catalyst. J. Chem. Eng. Jpn. 2011, 44, 328-335. [CrossRef]

11. Serrano-Lotina, A.; Daza, L. Influence of the operating parameters over dry reforming of methane to syngas. Int. J. Hydrog. Energy 2014, 39, 4089-4094. [CrossRef]

12. Karam, L.; Reboul, J.; El Hassan, N.; Nelayah, J.; Massiani, P. Nanostructured Nickel Aluminate as a Key Intermediate for the Production of Highly Dispersed and Stable Nickel Nanoparticles Supported within Mesoporous Alumina for Dry Reforming of Methane. Molecules 2019, 24, 4107. [CrossRef] [PubMed]

13. Karam, L.; Reboul, J.; Casale, S.; Massiani, P.; El Hassan, N. Porous Nickel-Alumina Derived from Metal-Organic Framework (MIL-53): A New Approach to Achieve Active and Stable Catalysts in Methane Dry Reforming. ChemCatChem 2020, 12, 373-385. [CrossRef] 
14. Shen, D.; Huo, M.; Li, L.; Lyu, S.; Wang, J.; Wang, X.; Zhang, Y.; Li, J. Effects of alumina morphology on dry reforming of methane over $\mathrm{Ni} / \mathrm{Al}_{2} \mathrm{O}_{3}$ catalysts. Catal. Sci. Technol. 2020, 10, 510-516. [CrossRef]

15. Sajjadi, S.M.; Haghighi, M.; Rahmani, F. Dry reforming of greenhouse gases $\mathrm{CH}_{4} / \mathrm{CO}_{2}$ over MgO-promoted $\mathrm{Ni}-\mathrm{Co} / \mathrm{Al}_{2} \mathrm{O}_{3}-\mathrm{ZrO}_{2}$ nanocatalyst: Effect of $\mathrm{MgO}$ addition via sol-gel method on catalytic properties and hydrogen yield. J. Sol-Gel Sci. Technol. 2014, 70, 111-124. [CrossRef]

16. Dias, J.A.C.; Assaf, J.M. Influence of calcium content in $\mathrm{Ni} / \mathrm{CaO} / \gamma-\mathrm{Al}_{2} \mathrm{O}_{3}$ catalysts for $\mathrm{CO}_{2}$-reforming of methane. Catal. Today 2003, 85, 59-68. [CrossRef]

17. Osman, A.I.; Abu-Dahrieh, J.K.; Cherkasov, N.; Fernandez-Garcia, J.; Walker, D.; Walton, R.I.; Rooney, D.W.; Rebrov, E. A highly active and synergistic $\mathrm{Pt} / \mathrm{Mo}_{2} \mathrm{C} / \mathrm{Al}_{2} \mathrm{O}_{3}$ catalyst for water-gas shift reaction. Mol. Catal. 2018, 455, 38-47. [CrossRef]

18. Hou, Z.; Yokota, O.; Tanaka, T.; Yashima, T. Investigation of CH4 Reforming with CO2 on Meso-Porous $\mathrm{Al}_{2} \mathrm{O}_{3}$-Supported Ni Catalyst. Catal. Lett. 2003, 89, 121-127. [CrossRef]

19. Abbas, H.F.; Wan Daud, W.M.A. Hydrogen production by methane decomposition: A review. Int. J. Hydrog. Energy 2010, 35, 1160-1190. [CrossRef]

20. Paksoy, A.I.; Caglayan, B.S.; Aksoylu, A.E. A study on characterization and methane dry reforming performance of Co-Ce/ZrO $\mathrm{Zr}_{2}$ catalyst. Appl. Catal. B Environ. 2015, 168-169, 164-174. [CrossRef]

21. Al-Fatesh, A.S. Promotional effect of Gd over Ni/ $\mathrm{Y}_{2} \mathrm{O}_{3}$ catalyst used in dry reforming of $\mathrm{CH}_{4}$ for $\mathrm{H}_{2}$ production. Int. J. Hydrog. Energy 2017, 42, 18805-18816. [CrossRef]

22. Al-Fatesh, A.S.; Ibrahim, A.A.; Abu-Dahrieh, J.K.; Al-Awadi, A.S.; El-Toni, A.M.; Fakeeha, A.H.; Abasaeed, A.E. Gallium-Promoted Ni Catalyst Supported on MCM-41 for Dry Reforming of Methane. Catalysts 2018, 8, 229. [CrossRef]

23. Al-Fatesh, A.S.; Atia, H.; Ibrahim, A.A.; Fakeeha, A.H.; Singh, S.K.; Labhsetwar, N.K.; Shaikh, H.; Qasim, S.O. $\mathrm{CO}_{2}$ reforming of $\mathrm{CH} 4$ : Effect of $\mathrm{Gd}$ as promoter for Ni supported over MCM-41 as catalyst. Renew. Energy 2019, 140, 658-667. [CrossRef]

24. Arbag, H.; Yasyerli, S.; Yasyerli, N.; Dogu, G. Activity and stability enhancement of Ni-MCM-41 catalysts by $\mathrm{Rh}$ incorporation for hydrogen from dry reforming of methane. Int. J. Hydrog. Energy 2010, 35, 2296-2304. [CrossRef]

25. Sharifi, M.; Haghighi, M.; Rahmani, F.; Karimipour, S. Syngas production via dry reforming of CH4 over Co- and $\mathrm{Cu}$-promoted $\mathrm{Ni} / \mathrm{Al}_{2} \mathrm{O}_{3}-\mathrm{ZrO}_{2}$ nanocatalysts synthesized via sequential impregnation and sol-gel methods. J. Nat. Gas Sci. Eng. 2014, 21, 993-1004. [CrossRef]

26. Park, J.-H.; Yeo, S.; Kang, T.-J.; Shin, H.-R.; Heo, I.; Chang, T.-S. Effect of Zn promoter on catalytic activity and stability of $\mathrm{Co} / \mathrm{ZrO} 2$ catalyst for dry reforming of CH4. J. CO2 Util. 2018, 23, 10-19. [CrossRef]

27. Schwarz, J.A.; Contescu, C.; Contescu, A. Methods for preparation of catalytic materials. Chem. Rev. 1995, 95, 477-510. [CrossRef]

28. Hao, Z.; Zhu, Q.; Jiang, Z.; Hou, B.; Li, H. Characterization of aerogel Ni/ $\mathrm{Al}_{2} \mathrm{O}_{3}$ catalysts and investigation on their stability for $\mathrm{CH}_{4}-\mathrm{CO}_{2}$ reforming in a fluidized bed. Fuel Process. Technol. 2009, 90, 113-121. [CrossRef]

29. Osman, A.I.; Abu-Dahrieh, J.K.; McLaren, M.; Laffir, F.; Rooney, D.W. Characterisation of Robust Combustion Catalyst from Aluminium Foil Waste. ChemistrySelect 2018, 3, 1545-1550. [CrossRef]

30. Jiménez-González, C.; Boukha, Z.; de Rivas, B.; González-Velasco, J.R.; Gutiérrez-Ortiz, J.I.; López-Fonseca, R. Behaviour of nickel-alumina spinel $\left(\mathrm{NiAl}_{2} \mathrm{O}_{4}\right)$ catalysts for isooctane steam reforming. Int. J. Hydrog. Energy 2015, 40, 5281-5288. [CrossRef]

31. Al-Fatesh, A.S.; Kumar, R.; Kasim, S.O.; Ibrahim, A.A.; Fakeeha, A.H.; Abasaeed, A.E.; Alrasheed, R.; Bagabas, A.; Chaudhary, M.L.; Frusteri, F.; et al. The effect of modifier identity on the performance of $\mathrm{Ni}$-based catalyst supported on $\gamma-\mathrm{Al}_{2} \mathrm{O}_{3}$ in dry reforming of methane. Catal. Today 2020, in press. [CrossRef]

32. Xu, J.; Zhou, W.; Wang, J.; Li, Z.; Ma, J. Characterization and Analysis of Carbon Deposited during the Dry Reforming of Methane over $\mathrm{Ni} / \mathrm{La}_{2} \mathrm{O}_{3} / \mathrm{Al}_{2} \mathrm{O}_{3}$ Catalysts. Chin. J. Catal. 2009, 30, 1076-1084. [CrossRef]

33. Hou, Z.; Yashima, T. Meso-porous Ni/Mg/Al catalysts for methane reforming with $\mathrm{CO}_{2}$. Appl. Catal. A Gen. 2004, 261, 205-209. [CrossRef]

34. Asai, K.; Takane, K.; Nagayasu, Y.; Iwamoto, S.; Yagasaki, E.; Inoue, M. Decomposition of methane in the presence of carbon dioxide over Ni catalysts. Chem. Eng. Sci. 2008, 63, 5083-5088. [CrossRef]

35. Li, X.; Li, D.; Tian, H.; Zeng, L.; Zhao, Z.-J.; Gong, J. Dry reforming of methane over $\mathrm{Ni}^{2} \mathrm{La}_{2} \mathrm{O}_{3}$ nanorod catalysts with stabilized Ni nanoparticles. Appl. Catal. B Environ. 2017, 202, 683-694. [CrossRef] 
36. Liu, D.; Lau, R.; Borgna, A.; Yang, Y. Carbon dioxide reforming of methane to synthesis gas over Ni-MCM-41 catalysts. Appl. Catal. A Gen. 2009, 358, 110-118. [CrossRef]

37. Zhang, J.; Li, F. Coke-resistant $\mathrm{Ni} @ S i O_{2}$ catalyst for dry reforming of methane. Appl. Catal. B Environ. 2015, 176-177, 513-521. [CrossRef]

(c) (C) 2020 by the authors. Licensee MDPI, Basel, Switzerland. This article is an open access article distributed under the terms and conditions of the Creative Commons Attribution (CC BY) license (http://creativecommons.org/licenses/by/4.0/). 